This is the author's final, peer-reviewed manuscript as accepted for publication. The publisher-formatted version may be available through the publisher's web site or your institution's library.

\title{
Black Friday and Cyber Monday: understanding consumer intentions on two major shopping days
}

Esther Swilley, Ronald E. Goldsmith

\section{How to cite this manuscript}

If you make reference to this version of the manuscript, use the following information:

Swilley, E., \& Goldsmith, R. E. (2013). Black Friday and Cyber Monday: Understanding consumer intentions on two major shopping days. Retrieved from http://krex.ksu.edu

\section{Published Version Information}

Citation: Swilley, E., \& Goldsmith, R. E. (2013). Black Friday and Cyber Monday: Understanding consumer intentions on two major shopping days. Journal of Retailing and Consumer Services, 20(1), 43-50.

Copyright: (C) 2012 Elsevier Ltd

Digital Object Identifier (DOI): doi:10.1016/j.jretconser.2012.10.003

Publisher's Link: http://www.sciencedirect.com/science/article/pii/S0969698912001233

This item was retrieved from the K-State Research Exchange (K-REx), the institutional repository of Kansas State University. K-REx is available at http://krex.ksu.edu 


\section{Black Friday and Cyber Monday: Understanding consumer intentions on two major shopping days}

- Esther Swilley ${ }^{\mathrm{a}}$

- Ronald E. Goldsmith ${ }^{\text {b, }}$

- ${ }^{a}$ Kansas State University, College of Business, 201A Calvin Hall, Manhattan, KS 665060506, USA

- $\quad{ }^{\mathrm{b}} 821$ Academic Way, Tallahassee, FL 32306-1110, USA

\section{Abstracts}

U.S. Retailers consider two major holiday shopping days as their most profitable - the Friday after Thanksgiving, Black Friday, and the Monday after Thanksgiving, Cyber Monday. Understanding consumer attitudes and intentions toward shopping in the mall or online at these times may aid retailers in their holiday marketing activities. This study uses data from a survey of 225 U.S. consumers to examine attitudes and behaviors of shoppers for these two shopping occasions. The results indicate that consumers enjoy shopping on Black Friday, yet were more likely to shop on Cyber Monday owing to its greater convenience. Retail managers will have a better opportunity to market on these two days with an understanding of consumer intentions for these major shopping occasions based on these findings.

\section{Keywords}

- Online shopping;

- Black Friday;

- Cyber Monday

\section{Introduction}

As retailers are concerned about how consumers shop on various channels, a look into habits during the peak holiday shopping season may give insight into multichannel shopping behavior. What are consumers' motivations during the prime shopping season, and how do they compare to previous studies of multichannel shopping behavior? What insights can we gather to aid retailers in developing marketing programs throughout the year for various retail channels? The goals of this research is to understand differences in attitudes and intentions between shoppers on Black Friday and those on Cyber Monday and to suggest how retailers can harness these differences in terms of marketing. Multichannel shoppers pose a challenge to retailers because understanding why consumers use specific channels is not apparent. We contribute to the 
literature by focusing on the most specific shopping activity during the year in hopes that using this particular microcosm of time of increased shopping activity can aid in understanding multichannel shopping activity for the rest of the year.

Winter holiday shopping accounts for $25-40 \%$ of the total U.S. annual retail sales (NRF, 2011). Because consumers spend so much during this period, retailers anxiously look forward to the holiday shopping season in order to achieve positive financial results for the year. During the holiday season, retailers rely heavily on advertising and consumer word-of-mouth to bring customers into stores and online to shop. In order to maximize their efforts, retailers are eager to understand consumer buying decisions that will aid them in achieving profits during this time.

The purpose of the present study is to understand consumer intentions to shop on these two sale days so that retailers can make better holiday promotion decisions. Understanding the shopping habits of holiday shoppers will allow retailers to realize why some consumers shop in the mall and others shop online. The contribution of this research is to understand consumer motivations during the two most important holiday shopping days and the factors behind this motivation. The objective is to understand theoretically these motivations in order to provide needed answers to retailers in terms of how to base their holiday marketing budgets.

With this information, retailers can develop campaigns that target their audiences based on consumer channel preference for holiday shopping. Oh and Kwon (2009) explore how consumers respond to price promotions during the holiday season in stores and on the Internet. No other academic literature, however, has focused on these two particular shopping days in terms of consumer attitudes toward shopping during the holiday season in stores and on the Internet, a gap that the present study fills. This research gives retailers an understanding of what motivates consumers to choose one or the other in terms of convenience and enjoyment.

\subsection{Holiday shopping}

Holiday shopping can be a two-edged sword for consumers. It can be a fun and enjoying experience when looking for gifts that will please the recipients. However, holiday shopping can also be unpleasant when consumers try to determine what to spend, how much to spend, and who to spend it on. The shopping experience can add either enjoyment or unpleasantness to holiday shopping. Moreover, with several retailing avenues now available, consumers must choose how to buy, whether online or offline.

There is a dearth of research in the area of holiday shopping, yet holiday shopping is a major source of revenue for retailers. Academic literature, in this instance, can substantiate the dollars spent on holiday shopping promotions and where those dollars should be placed (Oh and Kwon, $\underline{2009}$ and Suri, 1996). In turn, retailers can define their promotional activities in accordance with consumer shopping expectations at either the mall or online. We undertook this research to expand what is known about the influence of consumer attitudes on shopping intentions and specifically to aid retailers in understanding buying decisions during the prime holiday shopping season. We examine which channels consumers use for their holiday shopping, specifically, the two largest shopping days_-Black Friday and Cyber Monday. 
Retailers look forward to a banner year during the year-end holiday shopping season. Though the name Black Friday was first coined to connote traffic and congestion at stores following Thanksgiving (Apfelbaum, 1966), it is now synonymous with the day that retailers turn their books from the red ink of losses to the black ink of profits. Retailers use this day to bring customers to their stores with sales offerings, extended hours, and special promotions. The advent of the Internet, however, gives consumers a varied selection of channel options in which to conduct transactions.

In 2005, shop.org named the Monday after Thanksgiving Cyber Monday because many consumers who shopped during the prior weekend also did so online after going back to work on the following Monday. Cyber Monday is seen as a second day of major profits as sales surge on this day as well. Retailers use Black Friday promotions to lure shoppers to their stores, with extended shopping hours, hourly deals, and in-store promotions leading to increased Black Friday sales. Cyber Monday gives retailers the ability to extend those promotions, as well as offering a larger product selection for increased online sales. Cyber Monday is now the traditional beginning of the online holiday shopping season. It is believed that many people shop online during work hours on Cyber Monday and, as such, many retailers have begun to develop special sales and incentives for that particular shopping day. Cyber Monday is becoming a viable shopping option for many consumers, as consumers are still in the shopping mode and less productive during the workday. Cyber Monday also allows for dynamic pricing, where altering pricing is quick in order to compete with other online, as well as offline, merchants. $\underline{\mathrm{Oh}}$ and Kwon (2009) state that not only do promotions spur offline spending, but holiday spending on the Internet influences store spending during the holiday shopping season. Lee and Kim (2009) find that consumers are more likely to shop for others using the channel in which they shop for themselves.

U. S. Black Friday sales in 2009 were over \$595 million, up 11\% from 2008, even during a recessionary period (Comscore, 2009). Sales increased in 2010 to $\$ 648$ million (Comscore, 2010). Sales on Cyber Monday in 2009 were $\$ 887$ million, up five percent from 2008 (Comscore, 2009), and surpassed \$1 billion in Comscore (2010). Sales in the United Kingdom, for example, are expected to rise as many receive their last paycheck before Christmas during that time. Cyber Monday allows for purchasing and receiving gifts prior to holiday leave.

This paper describes holiday shopping intentions on these two critical retail-shopping days in terms of consumer marketing channel preference. Thomas and Peters (2011) explore Black Friday in terms of consumption rituals. They discuss how the impact of this single day of shopping has on retail sales. Because of its impact, retailers use this particular day for sales strategies not used throughout the year. Since 2005, Cyber Monday has also led retailers to develop promotion strategies not used online throughout the year. According to Thomas and Peters (2011), consumers also have different shopping rituals. We look specifically at these two days to understand how consumers find these two shopping days different from other shopping days of the year. Specifically, we want to understand the differences between the two days that both retailers and consumers have set aside as different.

We investigate the motivations of consumers during the prime holiday shopping season in order to aid retailers in the development of marketing programs that can help increase holiday sales. 
Specifically we address the question-what are consumers' motivations to shop at the mall on Black Friday or online on Cyber Monday? We develop a framework to identify the attitudes and intentions of shopping Black Friday and/or Cyber Monday. We specifically identify the elements that consumers take into account when shopping: the ease of shopping, the usefulness of the channel, convenience, and enjoyment. We also assess whether gender moderates these relationships. An examination of the theory behind these dimensions is offered. Afterwards, an analysis of the data, discussion, as well as implications for retailers are presented.

\section{Theory and hypotheses}

Retailers establish multichannel offering for customers - online (electronic commerce or mobile commerce) and offline (in-store or catalogue) - because retailers offering various channels for shopping can expect higher customer profitability (Venkatesh and Morris, 2000). The literature identifies several factors influencing the selection of one of these channel by consumers, including social influence (Warrington et al., 2007), demographics (Burke, 2002), previous experience with a retailer (Kumar and Venkatesan, 2005 and Teltzrow et al., 2007), and price (Choi and Mattila, 2009 and Tang and Xing, 2001). Frambach et al. (2007) examine segmentation in channel preference and find channel preference is driven by different drivers in each of the three buying stages (pre-purchase, purchase, and post-purchase). Segmentation of customers based on channel behavior is also investigated by Konus et al. (2008) and by McGoldrick and Collins (2007), who report that that multichannel shopping is a mainstream segment behavior, though customers can be segmented into those who enjoy shopping in a variety of channels, those who are store-focused, and others who are uninvolved. No research, however, focuses on the shopping behaviors of consumers during the two heaviest shopping days for U.S. retailers.

Keen et al. (2004) analyze the consumer decision-making process in terms of a brick-and-mortar store, catalogue, and Internet, suggesting that the Internet does not totally replace the retail store format. Goldsmith and Flynn (2005) report similar findings in their study of apparel shopping through these same channels. In terms of online shopping, consumers are more likely to use the Internet than physical stores for convenience and for the variety of items (Kim and Kim, 2006). What emerges from these findings is that consumers add new channels of distribution to their repertoire of buying modes and allocate spending across them depending on the task or the context of the buying decision. Our study examines how the specific context or situation (the two most active buying days in the U.S.) influences these decisions.

\subsection{Shopping convenience and perceived usefulness}

Consumers feel the pressure to get holiday shopping done during the time between Thanksgiving and Christmas. As Christmas approaches, time pressures increase (Miyazaki, 1993). Consumers want to be able to shop in an atmosphere that allows for ease in search time, reduction in search costs, and the ability to find products efficiently (Brown, 1989 and Childers et al., 2001). Rohm and Swaminathan (2004) refer to convenience as the time and effort saving experienced when purchasing goods/services. Convenience is a major motive for shopping online (Burke, 1997 and Jarvenpaa and Todd, 1997), and the intention to shop online is greater because of the convenience ( $\underline{\text { Chiang, } 2001}$ and Chiang and Dholakia, 2003) as consumers can shop at any time 
(Swaminathan et al., 1999). However, Kaufman-Scarborough and Lindquist (2002) show that convenience differs between those who tend to shop online as opposed to those who shop instore, as their perceptions of convenience differ. Consumers want shopping to be convenient, especially during the holiday season, meaning the ability to shop quickly, efficiently, and easily as easily as possible (Seiders et al., 2000).

In terms of convenience as a predictor of shopping motivations, Childers et al. (2001) find convenience to be a predictor of usefulness for online shopping, as well as a predictor of enjoyment of online shopping. We also examine convenience as a predictor of these determinants in terms of both Black Friday and Cyber Monday shopping. This approach differs from other findings in terms of convenience as we look specifically at the convenience of holiday shopping channels. Are shoppers really looking for convenience during the gift purchase experience? Lee and Kim (2009) suggest convenience is a motivator for using a channel for gift shopping, but do not go beyond the suggestion.

We think that consumers see going to the mall on Black Friday as convenient because consumers can find what is wanted and purchase it. However, they also view shopping online during Cyber Monday convenient because they can shop at work or at any time. There are no crowds, and the purchase can be hidden from gift recipients. Both Black Friday and Cyber Monday should be seen to be easy to use, as most consumers find the mall convenient, as they have most likely shopped at the mall previously and understand how to use it. Online shopping is also easy to use because most consumers now are used to doing so. Consumers perceive each mode to be useful in shopping for gifts because both offer larger selections during the holiday season than at other times. Therefore, we posit the following:

H1A: Shopping convenience is positively associated with perceived shopping usefulness for holiday shopping on Black Friday.

H1B: Shopping convenience is positively associated with perceived shopping usefulness for holiday shopping on Cyber Monday.

Several studies show that perceived usefulness significantly influences attitudes toward online shopping as well as influencing online purchase and repurchase intentions (Shih, 2004, Song and Zhang, 2004, Swilley and Goldsmith, 2007 and Vijayasarathy, 2004). The perceived usefulness of shopping either at the mall or online refers to the value of one particular channel over another. In other words, shopping at the mall on Black Friday may or may not be more useful in gift purchasing than shopping online during Cyber Monday. Shih (2004) shows that perceived usefulness significantly determine attitudes toward online shopping. Song and Zhang (2004) report positive influences for online repurchase intentions. Vijayasarathy (2004) finds usefulness significantly predicts attitude towards on-line shopping, and attitude toward on-line shopping strongly influences the intention to use on-line shopping. We extend this argument to understand the usefulness of holiday shopping on Black Friday and Cyber Monday. Consequently, our next two hypotheses are:

H2A. Perceived usefulness of shopping positively influences holiday shopping attitude on Black Friday. 
H2B. Perceived usefulness of shopping positively influences holiday shopping attitude on Cyber Monday.

\subsection{Shopping enjoyment}

During the holidays, many families go the mall together for shopping excursions. These experiences in shopping are looked at with either revelry or displeasure. Holiday shopping can be divided into hedonic and utilitarian motivations, as it is comprised of both escapism and tasking (Jin and Sternquist, 2004). Enjoyment has been found to motivate shopping (Arnold and Reynolds, 2003) and has been found to influence attitudes toward shopping (Childers et al.,

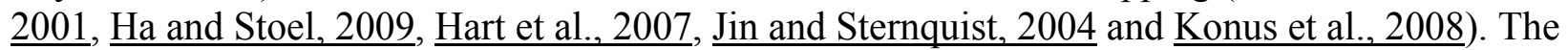
enjoyment found in holiday shopping can be both the escapism (finding a place to go and have fun) and task-related when seeking out the perfect gift. Shopping with others, the holiday decorations, and posing with Santa Claus adds to the retail store shopping enjoyment. Continuing mall shopping, escaping from work related activities, and the convenience of shopping alone can add to online shopping enjoyment. We surmise that convenience also adds to this holiday shopping enjoyment. Therefore, we hypothesize:

H3A: Shopping convenience is positively associated with perceived shopping enjoyment of holiday shopping on Black Friday.

H3B: Shopping convenience is positively associated with perceived shopping enjoyment of holiday shopping on Cyber Monday.

Babin et al. (1994) extol enjoyment as one of the hedonic fundamentals of shopping. Ha and Stoel (2009) show that enjoyment influences attitudes toward online shopping because shoppers who enjoy a website are most likely to shop on that particular site. Childers et al. (2001) find enjoyment to be a factor in a positive attitude toward an online store. However, there is evidence that enjoyment is more of a motivator for shopping offline than online (Dennis and McCall, $\underline{2005}$ and Rajamma et al., 2007). Given that consumers perceive holiday shopping to be enjoyable, and because of the influence of the experience, we put forward the following hypotheses:

H2A. Shopping enjoyment positively influences holiday shopping attitude on Black Friday.

H2B. Shopping enjoyment positively influences holiday shopping attitude on Cyber Monday.

\subsection{Intention to shop during the holidays}

Shopping attitudes leading to the intention to shop has been widely used for understanding what influences shopping intentions as shopping attitudes have been found to lead to positive shopping intentions (hen et al., 2002 and Vijayasarathy, 2004). Therefore, for holiday shopping, we posit, 
H5A. A positive attitude toward holiday shopping on Black Friday will lead to the intention to shop.

H5B. A positive attitude toward holiday shopping on Cyber Monday will lead to the intention to shop.

\subsection{Gender differences in holiday shopping}

As the number of female Internet users begins to outpace that of males (Williamson, 2008), retailers may need an understanding of gender differences when comparing online and offline shopping motivations. Intention to shop, either online or offline, may be influenced by gender (Alreck and Settle, 2002, Dholakia and Chiang, 2003, Laroche et al., 2005, Otnes and McGrath, 2001 and Zhou et al., 2007). Donthu and Garcia (1999) report no difference between online and offline shoppers in terms of gender. Venkatesh and Morris (2000) first look at gender differences in the framework of TAM and show that behavioral intentions for men are more strongly influenced by the perceived usefulness than they are for women. According to Zhou et al. (2007), based on factors related to online shopping, women are more skeptical of online shopping than men are, but men make more online purchases and spend more money online than women do; however, they are equal in terms of future online shopping.

Gender differences in holiday shopping have been explored in terms of attitudes (Fischer and Arnold, 1994) and purchase intentions (Chiu et al., 2005). Women enjoy shopping (Fischer and Arnold, 1994) and are influenced by the ease of purchasing (Chiu et al., 2005), while men are more utilitarian than women are in their shopping (Fischer and Arnold, 1994). Because of these differences, the genders more likely diverge in terms of shopping on Black Friday than on Cyber Monday. Women more than men are likely to enjoy the festivities of the holiday shopping experience, and may tend toward shopping on Black Friday with others at the mall. Men, on the other hand, are more likely than are women to shop online at work on Cyber Monday in order to get the shopping done. Because of these differences, we posit that:

H6A. Gender positively moderates the relationships of convenience, shopping enjoyment, and perceived usefulness with attitudes toward holiday shopping.

H6B. Gender positively moderates differences between attitudes toward holiday shopping and intentions to shop, specifically on Black Friday, when women are more likely to shop.

In summary, the study tests the fit of a model containing four constructs and four hypothesized relationships that are potentially moderated by gender. See Fig. 1. 

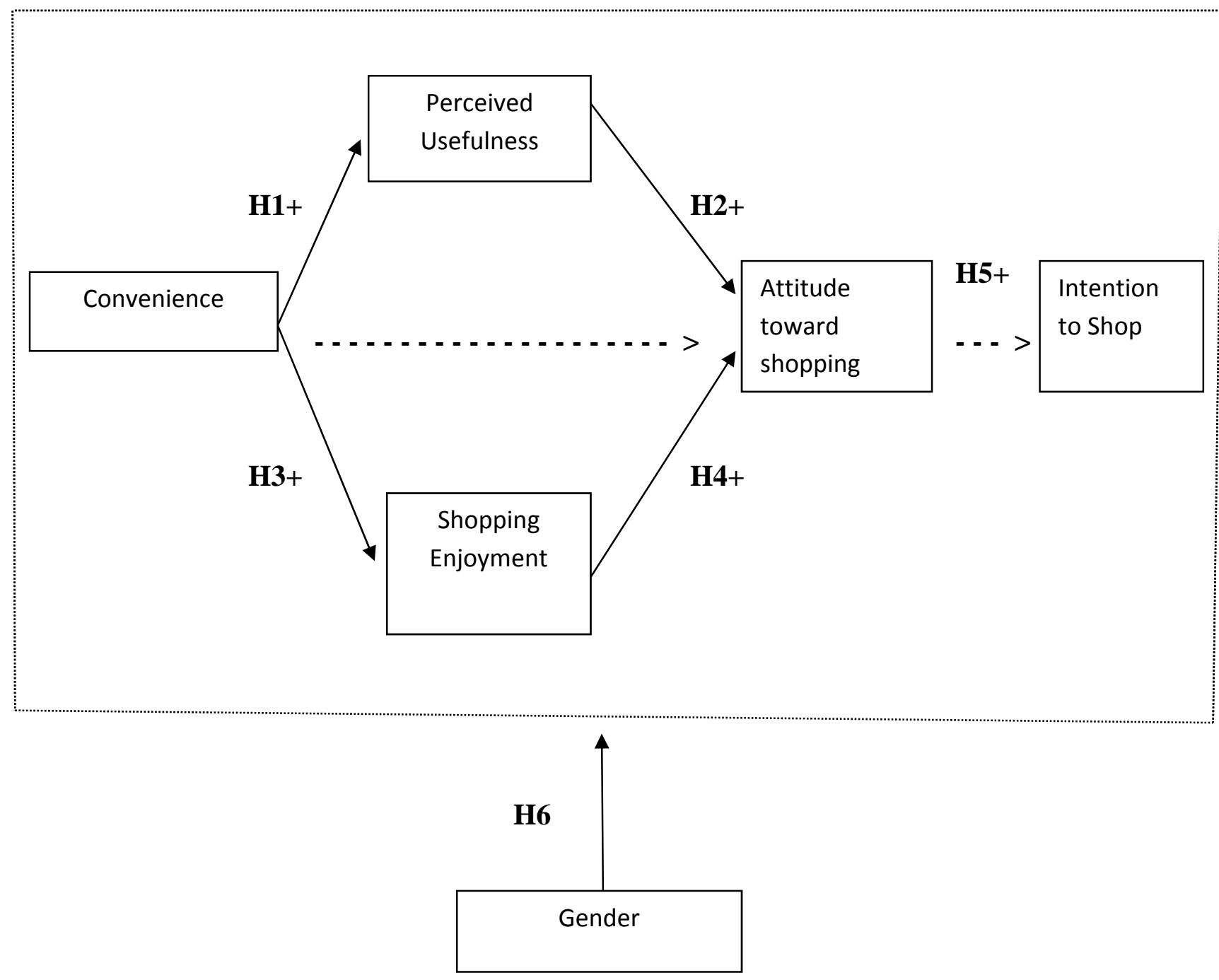

Fig. 1. Conceptual model.

\section{Research method}

\subsection{Data collection}

Data were obtained from business students at a Midwestern university. Participation was voluntary. Those who filled out the survey received extra credit. Students were also given extra credit for obtaining respondents from outside of the university. Although the sample includes shoppers from a variety of age groups, the student consumers of their generation take shopping very seriously, have a great deal of disposable income to spend, and shop frequently both offline and online (Yarrow and O'Donnell, 2009), so this data is suitable to test the hypotheses. 
Participants were given a description of Black Friday and Cyber Monday. Items on the questionnaire were the same for both Black Friday and Cyber Monday (see appendices for items). A total of 225 surveys were completed and usable, within the sample size range for structural equation modeling. Most of the survey respondents were between the ages of 19-24 (35\%), with $26 \%$ between the ages of 46-54. Twelve percent were ages $25-35,9 \%$ were ages $36-45,7 \%$ between the ages of 55-65, and 3\% greater than 65 years of age. The rest were either less than 18 or did not report. These were not used in the study. The split between genders skewed toward female with $58 \%$. Both genders were equally represented for all age categories. Only $2 \%$ of the participants never shopped online.

\subsection{Measures}

Constructs in this study were developed and modified from the existing literature. All constructs were measured as seven-point rating scales, using $1=$ strongly disagree to $7=$ strongly agree.

Specifically, perceived usefulness, attitude, and intentions were adapted from the TAM measures (Davis, 1989 and Davis et al., 1989). The items for the convenience and perceived enjoyment scales were derived from Childers et al. (2001). The items used appear in Table 1.

Table 1. Measures used in the study.

\section{Survey items: Cyber Monday}

\section{Item}

Convenience

Shopping online on the Monday after Thanksgiving is convenient.

Shopping online on the Monday after Thanksgiving saves me time.

Shopping online on the Monday after Thanksgiving is not time consuming.

Shopping online on the Monday after Thanksgiving is a convenient way to shop.

It does not take a lot of time and trouble to shop online on the Monday after Thanksgiving.

Perceived usefulness

Shopping online on the Monday after Thanksgiving is useful in buying what I want.

Shopping online on the Monday after Thanksgiving improves my shopping ability. .928

Shopping online on the Monday after Thanksgiving enhances my effectiveness in shopping.

Shopping online on the Monday after Thanksgiving improves my shopping productivity.

Shopping online on the Monday after Thanksgiving is useful in shopping.

Joy

Shopping online on the Monday after Thanksgiving will be fun. 


\section{Survey items: Cyber Monday}

Item $\lambda$

Shopping online on the Monday after Thanksgiving will be exciting. $\quad 955$

Shopping online on the Monday after Thanksgiving will be enjoyable. 954

Shopping online on the Monday after Thanksgiving will make me feel good. $\quad .908$

Attitude

Please respond to each statement that most closely represents how you feel about shopping online on the Monday after Thanksgiving.

$\begin{array}{llllllllll}\text { Bad } & 1 & 2 & 3 & 4 & 5 & 6 & 7 & \text { Good } & .910 \\ \text { Not beneficial } & 1 & 2 & 3 & 4 & 5 & 6 & 7 & \text { Beneficial } & .914\end{array}$

This survey contains questions concerning how you shop during the holidays. We are specifically looking at shopping at the mall on the day after Thanksgiving (known as Black Friday) and shopping online on the Monday after Thanksgiving (known as Cyber Monday). Your participation in the survey is voluntary. You will not be asked to identify yourself by name. The results will be anonymous. The questionnaire is confidential. The results of the research study may be published, but your name will not be used. Information obtained during the course of the study will remain confidential, to the extent allowed by law. Completion of this questionnaire will be considered your consent to participate. You must be at least 18 years old to participate.

\section{Table options}

\section{Data analysis and results}

In order to assess the relationships amongst the variables, the analysis includes both zero-order correlations and structural equation modeling. Zero-order correlations allow analysis of relationships between two variables without the overlap from other variables. Because zero-order correlations do not fully analyze the multivariate relationships, however, we then applied structural equation modeling to assess and define the structure of the model.

\subsection{Preliminary analyses}

Prior to testing the hypotheses, we assessed the relationships among the variables and with age and gender using zero-order correlations.

Our analyses also showed that overall the participants expressed more positive responses to all the Cyber Monday variables than to the Black Friday variables. Paired-samples $t$-tests found that for each pair of variables, the mean scores for Cyber Monday significantly $(p<.0005)$ exceeded those for Black Friday, and these results were identical for both men and women and seem consistent with recent evidence for the growing popularity of online shopping (Comscore, 2009). 
To assess the potential biasing influence of common method variance on the results, we examined the zero order correlations among the variables. Following the procedure described by Lindell and Whitney (2001), we determined the smallest correlation between the variables in the model using the same response format (method). This correlation proved to the one between Cyber Monday convenience and Black Friday enjoyment $(r=.007)$. This is the estimate of the impact of common method variance on the responses to the items. It is so low as to make it unlikely that the use of a common method added significant bias to the item responses. More conservatively, the correlation between Cyber Monday convenience and Black Friday convenience was only .031. Because these constructs were measured by items differing only in a few words (see Table 1), and sharing the same response format, we are confident that common method bias is not an issue in the data.

We assessed the convergent and discriminant validity of the measures using criteria described by Fornell and Larcker (1981) and tested the hypotheses with two-step Anderson and Gerbing (1988) analysis approach with a confirmatory factor analysis (CFA) followed by testing the comprehensive measurement model. Because the initial CFAs showed that the correlation between attitude and intention were so high they failed Fornell and Larcker's (1981) criteria. We removed intention from the model and tested its relationship with attitude separately. Because the presence of the attitude to intentions link is a well-accepted part of the TAM model and our failure to fit the model to this data was due to lack of discriminant validity (indicating how strongly related these two concepts are), removing intentions from the model is not a serious threat to the important findings of the study.

\subsection{Holiday shopping on Black Friday}

The results of the confirmatory factor analysis for Black Friday indicated a reasonable degree of model fit $\left(\chi^{2}=280.8, d f=98, \chi^{2} / d f=2.9, p<0.05\right)$. The $\mathrm{CFI}=.95$, the TLI $=.95, \mathrm{NFI}=.93$, the $\mathrm{SRMR}=.0335$, and the RMSEA $=.091$. All measurements included in the analysis were reliable, with construct reliabilities ranging from .85 to .96 . In addition, convergent validity was supported as all items loaded (see Table 1) significantly on their respective factors. Discriminant validity (see Table 2) is demonstrated in that the AVEs for each construct exceeded the squared correlations between them (Fornell and Larcker, 1981).

Table 2. Black Friday descriptive statistics and CFA results.

\begin{tabular}{llllllllll} 
Construct & \multicolumn{1}{c}{ Mean SD Alpha CR } & $\boldsymbol{R}^{2}$ & \multicolumn{3}{c}{ Conv Use } & Joy Attitude \\
Convenience & 13.5 & 7.7 .94 & .94 & & $(.76)$ & .66 & .69 & .44 \\
Usefulness & 16.8 & 7.9 .93 & .94 & .678 & .81 & $(.74)$ & .66 & .64 \\
Joy & 13.1 & 7.7 .96 & .96 & .706 & .83 & .83 & $(.86)$ & .59 \\
Attitude & 7.9 & 3.5 .85 & .85 & .646 & .66 & .80 & .77 & $(.74)$
\end{tabular}

Note: All correlations significant at the 0.01 level (2-tailed); $\mathrm{CR}=$ construct reliability; AVE is in parentheses on the diagonal; lower diagonal presents the correlation estimates from the CFA; upper diagonal contains the shared variances between the constructs. 


\section{$\underline{\text { Table options }}$}

A structural model tested the first four hypotheses. This model also fit the data reasonably well $\left(\chi^{2}=323.6, d f=100, \chi^{2} / d f=3.2, p<0.05\right)$. The $\mathrm{CFI}=.95$, the $\mathrm{TLI}=.93, \mathrm{NFI}=.92$, the $\mathrm{SRMR}=.0585$, and the RMSEA $=0.10$. The standardized path coefficients representing hypotheses one through four appear in Table 4. The coefficients are all positive and significant, indicating support for hypotheses one through four. Perceived convenience of shopping on Black Friday is positively linked to the perceived usefulness and enjoyment of shopping on Black Friday, while perceived usefulness and enjoyment are linked positively to attitude toward shopping on Black Friday.

Table 3. Cyber Monday descriptive statistics and CFA results.

\begin{tabular}{|c|c|c|c|c|c|c|c|c|}
\hline Construct & Mean & SD Al & CR & $R^{2}$ & Conv & Use & Joy & Attitude \\
\hline Convenience & 23.9 & 7.59 .94 & .94 & & $(.77)$ & .72 & .50 & .52 \\
\hline Usefulness & 22.0 & 7.39 .95 & .95 & .744 & .85 & $(.79)$ & .52 & .59 \\
\hline Joy & 16.0 & 6.09 .96 & .96 & 523 & .71 & .72 & $(.87)$ & .40 \\
\hline Attitude & 9.8 & 3.11 .91 & .91 & 610 & .72 & .77 & .63 & $(.83)$ \\
\hline
\end{tabular}

Note: All correlations significant at the 0.01 level (2-tailed); $\mathrm{CR}=$ construct reliability; $\mathrm{AVE}$ is in parentheses on the diagonal; lower diagonal presents the correlation estimates from the CFA; upper diagonal contains the shared variances between the constructs.

$\underline{\text { Table options }}$

Table 4. Hypothesized paths.

\begin{tabular}{|c|c|c|c|c|c|}
\hline \multirow{2}{*}{ Hypothesis } & \multirow{2}{*}{ Path } & \multirow[b]{2}{*}{ SPC } & \multirow[b]{2}{*}{$t$-test } & \multirow[b]{2}{*}{ SPC } & \multirow[b]{2}{*}{$t$-test } \\
\hline & & & & & \\
\hline $\mathrm{H} 1$ & Conv----->Use & .824 & 12.7 & .863 & 13.0 \\
\hline $\mathrm{H} 2$ & Use----->Att & .507 & 6.7 & .665 & 9.0 \\
\hline $\mathrm{H} 3$ & Conv----> Joy & .840 & 15.8 & .723 & 11.7 \\
\hline $\mathrm{H} 4$ & Joy----->Att & .364 & 5.1 & .168 & 2.6 \\
\hline
\end{tabular}

Note: $n=225 ; d f=100 ; \mathrm{SPC}=$ standardized path coefficient; all $t$-tests significant at $p<.01$.

\section{Table options}

Intention to shop on Black Friday/Cyber Monday was measured with two items: "I intend to shop [at the Mall/online] on the [day/Monday] after Thanksgiving" and "Shopping at the Mall/online on the day/Monday after Thanksgiving is a good idea" (alphas=.88 and .77). Because a CFA initially showed that the measures for attitude toward shopping on Black Friday and intention to shop on Black Friday failed to meet Fornell and Larcker's (1981) criteria for discriminant validity (the squared correlations exceeded the AVEs for both constructs) intention 
to shop was not included in the structural model test. To test hypothesis five, we computed the zero-order correlation between attitude toward shopping on Black Friday with intention to shop on Black Friday and computed a 95\% confidence interval on the result. The correlation was .72 $(p<.001)$ with a $95 \%$ confidence interval of .653-779. Because the confidence interval does not contain 1.0, we feel there is sufficient evidence that attitude does predict shopping intention and thus hypothesis five is supported.

We also tested an alternative model in which there was a direct path from convenience to attitude toward shopping. This model did not fit the data as well as the hypothesized model, and the standardized path coefficient was not significant, indicating that the relationship between convenience and shopping attitude for Black Friday is completely mediated by usefulness and enjoyment. This surmise is supported by the results of mediation testing using the analysis proposed by Preacher and Hayes (2004). This test showed that the direct effect of convenience on attitude when usefulness and enjoyment acted as mediators was not significant $(p=.1037)$.

\subsection{Holiday shopping on Cyber Monday}

The results of the confirmatory factor analysis for Cyber Monday indicated a reasonable degree of model fit $\left(\chi^{2}=241.0, d f=98, \chi^{2} / d f=2.5, p<0.05\right)$. The CFI $=.97$, the TLI $=.96, \mathrm{NFI}=.94$, the $\mathrm{SRMR}=.0298$, and the $\mathrm{RMSEA}=.081$. All measurements included in the analysis were reliable, with construct reliabilities ranging from .91 to .96 . In addition, convergent validity was supported as all items loaded (see Table 1) significantly on their respective factors. Discriminant validity (see Table 3 ) is demonstrated in that the AVEs for each construct exceeded the squared correlations between them (Fornell and Larcker, 1981).

A structural model tested the first four hypotheses. This model also fit the data reasonably well $\left(\chi^{2}=259.7, d f=100, \chi^{2} / d f=2.6, p<0.05\right)$. The CFI=.96, the TLI=.95, NFI=.94, the SRMR=.046, and the RMSEA $=0.84$. The standardized path coefficients representing hypotheses one through four appear in Table 4. The coefficients are all positive and significant, indicating support for hypotheses one through four. Perceived convenience of shopping on Cyber Monday is positively linked to the perceived usefulness and enjoyment of shopping on Cyber Monday, while perceived usefulness and enjoyment are linked positively to attitude toward shopping on Cyber Monday.

Again, we tested hypothesis five, that attitude toward shopping on Cyber Monday was positively linked with intention to shop on Cyber Monday by computing the correlation between the measures and placing a 95\% confidence interval around it. The zero-order correlation was .62 $(p<.001)$ and the 95\% confidence interval was .531-694. Because the interval did not contain 1.0 we conclude that hypothesis five is supported and that a positive attitude toward shopping on Cyber Monday is linked to intention to shop on that day.

Finally, we tested the alternative model containing a direct link from convenience to attitude. This model did not fit the data was well as the hypothesized model and the hypothesized path was not significant. This result suggests that usefulness and enjoyment fully mediate the relationship between convenience and attitude. We confirmed this suggestion using the mediation analysis suggested by Preacher and Hayes (2004). This test showed that the direct 
effect of convenience on attitude when usefulness and enjoyment acted as mediators was not significant $(p=.0579)$.

\subsection{Moderation by gender}

We used $t$-tests to assess if there were any gender difference in the variables. These tests showed that none was significant; that is, there were no statistically significant differences in mean scores between men and women for any of the variables in the model for either Black Friday or Cyber Monday. We assessed the moderating effects of gender on the model (H6A and H6B) by using multigroup structural equation modeling analyses. The model shown in Fig. 1 was tested for men and women separately for Black Friday and then for Cyber Monday. The procedure was to create a baseline model in which the four standardized path coefficients were constrained to be equal. Then, a second model was estimated in which the individual paths were allowed to vary freely. The results of both models were then used to test for chi-square differences for the path coefficients. These analyses showed that there were no statistically significant evidence for systematic differences in the model between men and women for either Black Friday or Cyber Monday. It appears that in this sample of consumers, gender does not moderate the relationships among the other variables, thus failing to support H6A or H6B.

\section{Discussion}

This study is the first to investigate theoretically consumer motivations for holiday shopping on the two most profitable retail shopping days-Black Friday and Cyber Monday. The results indicate both similarities and differences in consumers' motivations, attitudes, and intentions in shopping at the mall on Black Friday, or online on Cyber Monday. Consumers found Cyber Monday much more convenient than Black Friday, which coincides with other research that has found online shopping more convenient than store shopping. However, when used as an antecedent to perceived usefulness, Cyber Monday and Black Friday were close to equivalent. Both were seen as useful in holiday gift shopping. It is probable that consumers use both Black Friday and Cyber Monday for their gift needs. Mall shopping for gifts is convenient because consumers can take advantage of sales and promotions for coveted products, such as the latest toy or electronic product. However, Cyber Monday allows consumers a better selection of gift choices, price shopping, and delivery of gifts (Balasubramanian et al., 2005).

Consumers found more enjoyment in shopping at the mall on Black Friday than shopping online on Cyber Monday. The findings also suggest that even though enjoyment leads to a positive attitude toward shopping either at the mall or online, it has a significant bearing on the intention to shop during these two days. Enjoyment of the holiday shopping experience leading to the intention to shop on Black Friday was more impactful than the intention to shop on Cyber Monday. The opportunity to shop with others, see Santa Claus, as well as experience the holiday decorations, makes the mall shopping experience enjoyable. Online shopping lacks these experiences, and can be anxiety-driven when caught shopping instead of working.

Although respondents found more enjoyment in shopping at the mall, the intention to shop online on Cyber Monday was far greater than the intention to shop at the mall on Black Friday, based on attitude toward shopping on that particular shopping day. A possible explanation is that 
since usefulness is the main predictor of a positive attitude toward online shopping, that consumers intend to shop online because they feel it will be useful for their holiday shopping needs. It aids in understanding what is happening in the marketplace-consumers shop at the mall on Black Friday, and follow up their shopping on Cyber Monday. As far as gender is concerned, there is no difference between the sexes in terms of shopping online for the holidays. Each is likely to shop online on Cyber Monday. However, women are almost twice as likely to shop at the mall on Black Friday as men are.

As with any study, this research has its limitations. Though it was not dependent upon a university study, the sample was limited to a particular geographic area. Further studies could expand on the type of respondents by geography. In addition, the types of retail establishments that consumers intend to shop can be identified to explore the type of products consumers tend to buy on Black Friday as opposed to Cyber Monday. Moreover, since this study identified shopping attitudes and intentions, an extension could provide additional information concerning actual purchase behavior on these shopping days.

\subsection{Managerial implications}

With the arrival of Cyber Monday, retailers now have two major shopping days during holiday shopping. Both Black Friday and Cyber Monday offer retailers the ability to increase yearly revenues and get a good start to the holiday shopping season. The ability to integrate sales and promotions allows retailers the ability to get the most out of each channel. This research aids retailers in understanding consumer attitudes toward two shopping channels for holiday shopping and maximizing the benefits of each one.

Black Friday offers consumers an enjoyable shopping experience. Many families use this opportunity to shop together after the Thanksgiving holiday. Many malls bring in Santa Claus, offering photos with Santa and many activities for children. Retailers have used this day to open early in the morning for those shoppers who like to take advantage of hourly specials. Overall, this research finds that consumers find Black Friday shopping to be convenient and enjoy the experience. Retailers should continue to enhance the shopping experience, as well as understanding why consumers want to shop on this day. Promotions, specials and other communications should stress the advantages of Black Friday shopping - useful for gift purchasing.

Cyber Monday offers a very different holiday shopping experience. Consumers are likely to use Cyber Monday to continue their weekend gift purchasing. Online shopping offers consumers the opportunity to purchase gifts they were unable to purchase at the mall, or gifts to be delivered directly to the recipients. As consumers find both Black Friday and Cyber Monday useful for holiday shopping, retailers need to integrate both channels in their communications. Many retailers are now offering a combination of promotional offers that can be used by consumers that use both channels. Promotion integration allows for multichannel shopping. Retailers can extend this opportunity with promotions for those who shop on Black Friday that can be used on Cyber Monday. There may also be an opportunity to increase female consumer shopping online. 
In conclusion, this study extends retail shopping research by examining holiday shopping on the two main holiday shopping days. These two shopping days work just as well for consumers as each offers distinct experiences and usefulness for holiday shopping needs.

\section{References}

Alreck, P.L. and Settle, R.B., 2002. Gender effects on internet, catalogue, and store shopping. Journal of Database Marketing 9 (2), 150-162.

Anderson, J.C. and Gerbing, D.W., 1988. Structural equation modeling in practice: a review and recommended two-step approach. Psychological Bulletin, 103 (3), 411-423.

Apfelbaum, M. L., 1966. Philadelphia's 'Black Friday. The American Philatelist 79 (4), 239.

Arnold, M.J. and Reynolds, K.E., 2003, Hedonic shopping motivations. Journal of Retailing 79, 77-95.

Babin, B.J., Darden, W.R. and Griffin, M., 1994. Work and/or fun: measuring hedonic and utilitarian shopping value. The Journal of Consumer Research 20 (4), 644-656.

Balasubramanian, S., Raghunathan, R. and Mahajan, V., 2005. Consumers in a multichannel environment: product utility, process utility, and channel choice. Journal of Interactive Marketing 19 (2), 12-30.

Brown, L.G., 1989. The strategic and tactical implications of convenience in consumer product marketing, The Journal of Consumer Marketing 6 (June), 13-20.

Burke, R., 1997. Do you see what I see? The future of virtual shopping. Journal of the Academy of Marketing Science 25 (4), 352-360.

Burke, R., 2002. Technology and the customer interface: what consumers want in the physical and virtual store. Academy of Marketing Science. Journal 30, 411-433.

Chiang, K., 2001. Effects of price, product type, and convenience on consumer intention to shop online. in American Marketing Association Conference Proceedings, Chicago, IL Winter, 163-169.

Chiang, K. and Dholakia, R.R., 2003. Factors driving consumer intention to shop online: an empirical investigation. Journal of Consumer Psychology 13 (1/2), 177-183.

Chen, L., Gillenson, M.L. and Sherrell, D.L., 2002. Enticing online consumers: an extended technology acceptance perspective, Information \& Management 39, 705-719.

Childers, T.L., Carr, C.L., Peck, J. and Carson, S., 2001. Hedonic and utilitarian motivations for online retail shopping behavior. Journal of Retailing 77, 511-535. 
Chiu, Y., Lin, C. and Tang, L., 2005. Gender differs: assessing a model of online purchase intentions in e-tail service. International Journal of Service Industry Management 16, 416-435.

Choi, S. and Mattila, A.S., 2009. Perceived fairness of price differences across channels: the moderating role of price frame and norm perceptions. The Journal of Marketing Theory and Practice 17 (Winter), 37-48.

Comscore, 2009. Retrieved May 3, 2010 from http://www.comscore.com/Press_Events/Press_Releases/2009/12/Cyber_Monday_Online _Sales_Up_5_Percent_vs._Year_Ago_to_887_Million_to_Match_Heaviest_Online_Spen ding_Day_in_History.

Comscore, 2010. Retrieved November 16, 2011 from http://www.comscore.com/Press_Events/Press_Releases/2010/12/Billion_Dollar_Bonanz a_Cyber_Monday_Surpasses_1_Billion_in_U.S._Spending.

Cox, A.D., Cox, D. and Anderson, R.D., 2005. Reassessing the pleasures of store shopping, Journal of Business Research 58 No. 3, 250-259.

Davis, F.D., 1989. Perceived usefulness, perceived ease of use, and user acceptance of information technology, MIS Quarterly 13 No. 3, 319-340.

Davis, F.D., Bagozzi, R.P. and Warshaw, P.R., 1989. User acceptance of computer technology: a comparison of two theoretical models. Management Science 35 (August), 982- 1003.

Dennis, C. and McCall, A., 2005. The savannah hypothesis of shopping. Business Strategy Review 16 (3), 12-16.

Dholakia, R.R. and Chiang, K., 2003. Shoppers in cyberspace: are they from Venus or mars and does it matter? Journal of Consumer Psychology 13 (1/2), 171-176.

Donthu, N. and Garcia, A., 1999. The internet shopper. Journal of Advertising Research 39 No. 3, 52-58.

Fischer, E. and Arnold, S.J., 1994. Sex, gender identity, gender role attitudes, and consumer behavior. Psychology \& Marketing 11 (2), 163-183.

Fornell, C. and Larcker, D.F., 1981. Evaluating structural equation models with unobservable variables and measurement error. Journal of Marketing Research 18 (1), 39-50. 
Frambach R.T., Roest, H.C.A. and Krishnan, T.V., 2007. The impact of consumer internet experience on channel preference and usage intentions across the different stages of the buying process. Journal of Interactive Marketing 21 (Spring), 26-41.

Goldsmith, R.E., 2000. How innovativeness distinguishes online buyers. Quarterly Journal of Electronic Commerce 1 (4), 323-333.

Goldsmith, R.E. and Flynn, L., 2005. Bricks, clicks, and pix: apparel buyers' use of stores, internet and catalogs compared. International Journal of Retail \& Distribution Management 33 (4), 271-283.

Ha, S. and Stoel, L., 2009. Consumer e-shopping acceptance: antecedents in a technology acceptance model. Journal of Business Research 62, 565-571.

Hart, C.A., Farrell, A.M., Stachow, G.B., Reed, G.M. and Cadogan, J.W., 2007. Enjoyment of the shopping experience: impact on customers' repatronage intentions and gender influence", The Service Industries Journal 27 (July), 583-604.

Jarvenpaa, S.L. and Todd, P.A., 1997. Is there a future for retailing on the internet? in Electronic Marketing and the Consumer, Robert A. Peterson, ed. Thousand Oaks, CA: Sage, 139154.

Jin, B. and Sternquist, B., 2004. Shopping is truly a joy. The Services Industries Journal 24 (November), 1-18.

Kaufman-Scarborough, C. and Lindquist, J.D., 2002. E-shopping in a multiple channel environment. The Journal of Consumer Marketing 19 (4/5), 333-350.

Keen, C., Wetzels, M., de Ruyter, K. and Feinberg, R., 2004. E-tailers versus retailers: which factors determine consumer preferences? Journal of Business Research 57, 685-695.

Kim, K. and Kim, E.B., 2006. Suggestions to enhance the cyber store customers' satisfaction. Journal of American Academy of Business 9 (1), 233-240.

Konus, U., Verhoef, P.C. and Neslin, S.A., 2008. Multishopper segments and their covariates. Journal of Retailing 84, 398-413.

Kumar, V. and Venkatesan, R., 2005. Who are multichannel shoppers and how do they Perform? Correlates of multichannel shopping behaviour. Journal of Interactive Marketing 19, $44-61$. 
Laroche, M., Yang, Z., McDougall, G.H.G. and Bergeron, J., 2005. Internet versus bricks-andmortar retailers: an investigation into intangibility and its consequences. Journal of Retailing 81, 251-267.

Lee, H. H. and Kim, J., 2009. Gift shopping behavior in a multichannel retail environment. The role of personal purchase experiences. International Journal of Retail \& Distribution Management 37 (5), 420-439.

Lindell, M.K. and Whitney, D.J., 2001. Accounting for common method variance in crosssectional research designs. Journal of Applied Psychology, 86 (1), 114-121.

McGoldrick, P.J. and Collins, N., 2007. Multichannel retailing: profiling the multichannel shopper. International Review of Retail, Distribution, and Consumer Research 17 (2), 139-158.

Miyazaki, A.D., 1993. How many shopping days until Christmas? A preliminary investigation of time pressures, deadlines, and planning levels on holiday gift purchases. Advances in Consumer Research, ed. Leigh McAlister and Michael L. Rothschild, Provo, UT: Association for Consumer Research, 331-335.

NRF, 2011. Retrieved February 7, 2012 from http://www.nrf.com/modules.php?name=Pages\&sp_id=1140

Oh, H. and Kwon, K., 2009. An exploratory study of sales promotions for multichannel holiday shopping. International Journal of Retail and Distribution Management 37 (10), 867-887.

Otnes, C. and McGrath, M.A., 2001. Perceptions and realities of male shopping behavior. Journal of Retailing 77, 111-137.

Preacher, K.J. and Hayes, A.F., 2004. SPSS and SAS procedures for estimating indirect effects in simple mediation models. Behavior Research Methods Instruments \& Computers, 36 (4), 717-731.

Rajamma, R.K., Paswan, A.K. and Ganesh, G., 2007. Services purchased at brick and mortar versus online stores, and shopping motivation. The Journal of Services Marketing 21 (3), 200-212.

Rohm, A.J. and Swaminathan, V., 2004. A typology of online shoppers based on shopping motivations. Journal of Business Research 57 (7), 748-757.

Seiders, K., Berry, L.L., and Gresham L.G., 2000. Attention, retailers! How convenient is your convenience strategy? Sloan Management Review 41 (Spring), 79-89. 
Shih, H., 2004. An empirical study on predicting user acceptance of e-shopping on the web. Information \& Management 41, 351-368.

Song, J.H. and Zhang, J.Q., 2004. Why do people shop online? Exploring the quality of the online shopping experience. American Marketing Association. Conference Proceedings, 2004 AMA Winter Educators' Conference 15, 154-160.

Suri, R., 1996. Poor performance of retail during Christmas season: a case for changing price promotions. Pricing Strategy \& Practice 4 (2), 32-35.

Swaminathan, V., Lepkowska-White, E. and Rao, B.P., 1999. Browsers or buyers in cyberspace? An investigation of factors influencing likelihood of electronic exchange. Journal of Computer-Mediated Communication 5 (2).

Swilley, E. and Goldsmith, R.E., 2007. The role of involvement and experience with electronic commerce in shaping attitudes and intentions toward mobile commerce. in the International Journal of Electronic Marketing and Retailing 1 (4), 370-384.

Tang, F. and Xing, X., 2001. Will the growth of multi-channel retailing diminish the pricing efficiency of the web? Journal of Retailing 77, 319-333.

Teltzrow, M., Meyer, B. and Lenz, H.J., 2007. Multi-channel consumer perceptions. Journal of Electronic Commerce Research 8 (Feb), 18-31.

Thomas, J.B., Peters, C., 2011. An exploratory investigation of black friday consumption rituals. International Journal of Retail and Distribution Management 39 (7) 522- 537.

Venkatesh, V. and Morris, M.G., 2000. Why don't men ever stop to ask for directions? Gender, social influence, and their role in technology acceptance and usage behavior. MIS Quarterly 24, 115-139.

Vijayasarathy, L., 2004. Predicting consumer intentions to use on-line shopping: the case for an augmented technology acceptance model. Information \& Management 41, 747-762.

Warrington, P. T., Gangstad, E. and Feinberg, R., 2007. Multi-channel retailing and customer satisfaction: implications for E-CRM. International Journal of E-Business Research 3 (2), 57-69.

Williamson, D. A., 2008. Men, you're outnumbered online. (accessed May 18, 2010), http://www.emarketer.com/Article.aspx?id=1006082\&src=article1_newsltr. 
Yarrow, K. and O'Donnell, J. 2009. Gen Buy: How Tweens, Teens, and Twenty-Somethings are Revolutionizing Retail, Jossey-Bass, San Francisco, CA.

Zhou, L., Dai, L. and Zhang, D., 2007. Online shopping acceptance model - a critical survey of consumer factors in online shopping. Journal of Electronic Commerce Research 8 (1), 41 62.

Corresponding author. Tel.: +1 7855326135.

Copyright (C) 2012 Elsevier Ltd. All rights reserved. 